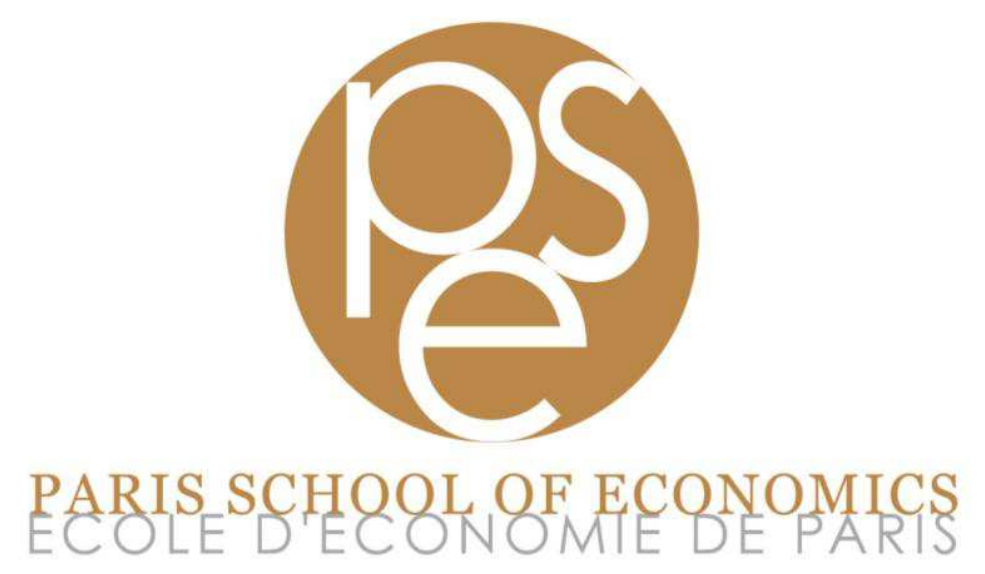

The Impact of Market Regulations on Intra-European Real Exchange Rates

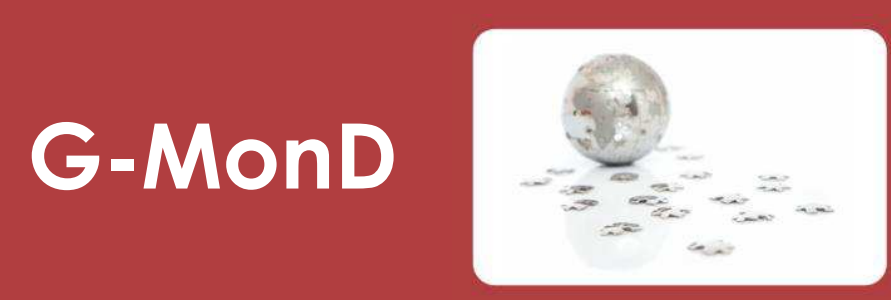

Working Paper $\mathbf{n}^{\circ} \mathbf{2 8}$

For sustainable and inclusive world development 


\title{
The Impact of Market Regulations on Intra-European Real Exchange Rates*
}

\author{
Agnès Bénassy-Quéré \\ Paris School of Economics, University Paris 1 and CESIfo. \\ Dramane Coulibaly \\ EconomiX-CNRS, University of Paris Ouest.
}

\begin{abstract}
We study the contribution of market regulations in the dynamics of the real exchange rate within the European Union. Based on a model proposed by De Gregorio et al. (1994a), we show that both product market regulations in nontradable sectors and employment protection tend to inflate the real exchange rate. We then carry out an econometric estimation for European countries over 1985-2006 to quantify the contributions of the pure Balassa-Samuelson effect and those of market regulations in real exchange-rate variations. Based on this evidence and on a counter-factual experiment, we conclude that the relative evolution of product market regulations and employment protection across countries play a very significant role in real exchangerate variations within the European Union and especially within the Euro area, through theirs impacts on the relative price of nontradable goods.
\end{abstract}

Keywords: Real exchange rate, Balassa-Samuelson effect, Product market regulations, Employment protection

JEL classification: F41, J50, L40.

*This paper was written while both authors were researchers at CEPII. We are thankful to Gunther Capelle-Blancard, Benjamin Carton, Jacques Melitz and Valérie Mignon for their remarks on a preliminary version. The usual disclaimer applies. 


\section{Introduction}

One key feature of the sovereign debt crisis that hit several countries of the Euro area in 2008 and following years was a sudden stop of private capital inflows, which had to be taken over by official financings (Member states, European Financial Stability Facility, International Monetary Fund), and by the intra-Euro area payment system (TARGET2). ${ }^{1}$ Indeed, crisis countries generally displayed twin deficits, i.e. a fiscal deficit and a current account deficit. Unlike Japan, these countries were unable to rely on domestic private savings to refinance their government debt, making them vulnerable to a sudden stop in external financing. ${ }^{2}$ The policy debate then pointed price divergence within the Euro area as one major cause of the crisis. As evidenced in Figure 1, from 1999 to 2008, the consumer price index increased by $17 \%$ in Germany against 36\% in Greece and Ireland, 34\% in Spain, 30\% in Portugal and $25 \%$ in Italy. Such price divergence would not have been worrisome should it have corresponded to a catch-up process, consistent with the Balassa-Samuelson effect (BS effect, hereafter, see Balassa (1964) and Samuelson (1964)). ${ }^{3}$ In 1999, however, Ireland had already caught up with Germany in terms of GDP per capita. In the other countries, although part of the price divergence observed during the decade may be explained by the BS effect, the extent of the drift calls for alternative explanations.

The consumer price index covers both tradable and nontradable goods. Excess price increase in tradable sectors impacts price competitiveness visà-vis foreign competitors, with a negative, demand-side effect on exports. In turn, excess price increase in nontradable sectors acts as an incentive to transfer resources from the tradable sectors to the nontradable ones, with a negative, supply-side effect on exports. This latter effect is often overcome by international trade analyses that tend to focus on the relative price of tradables across countries rather than their relative price compared to nontradables. Still, the bulk of price divergences observed between 1999 and 2006 within the Euro area seems to be attributable to nontradable sectors, as evidenced in Figure 2. This suggests that the supply-side effect may have been a significant driver of current account deficits over the period.

The question then is how to explain such divergences in nontradable prices beyond the BS effect. We argue that the relaxation of the assumption of per-

\footnotetext{
${ }^{1}$ See, eg., Merler and Pisani-Ferry (2012).

${ }^{2}$ See Gros (2011).

${ }^{3}$ The BS effect states that, assuming the law of one price holds for tradable goods, productivity growth in this sector pushes real wages up both in the tradable sector and (through labor mobility) in the nontradable one. This results in an increase in the relative price of nontradables and thus in a real exchange-rate appreciation.
} 
Figure 1: Harmonized consumer price index in Euro area countries, 1999$2011(1999=100)$

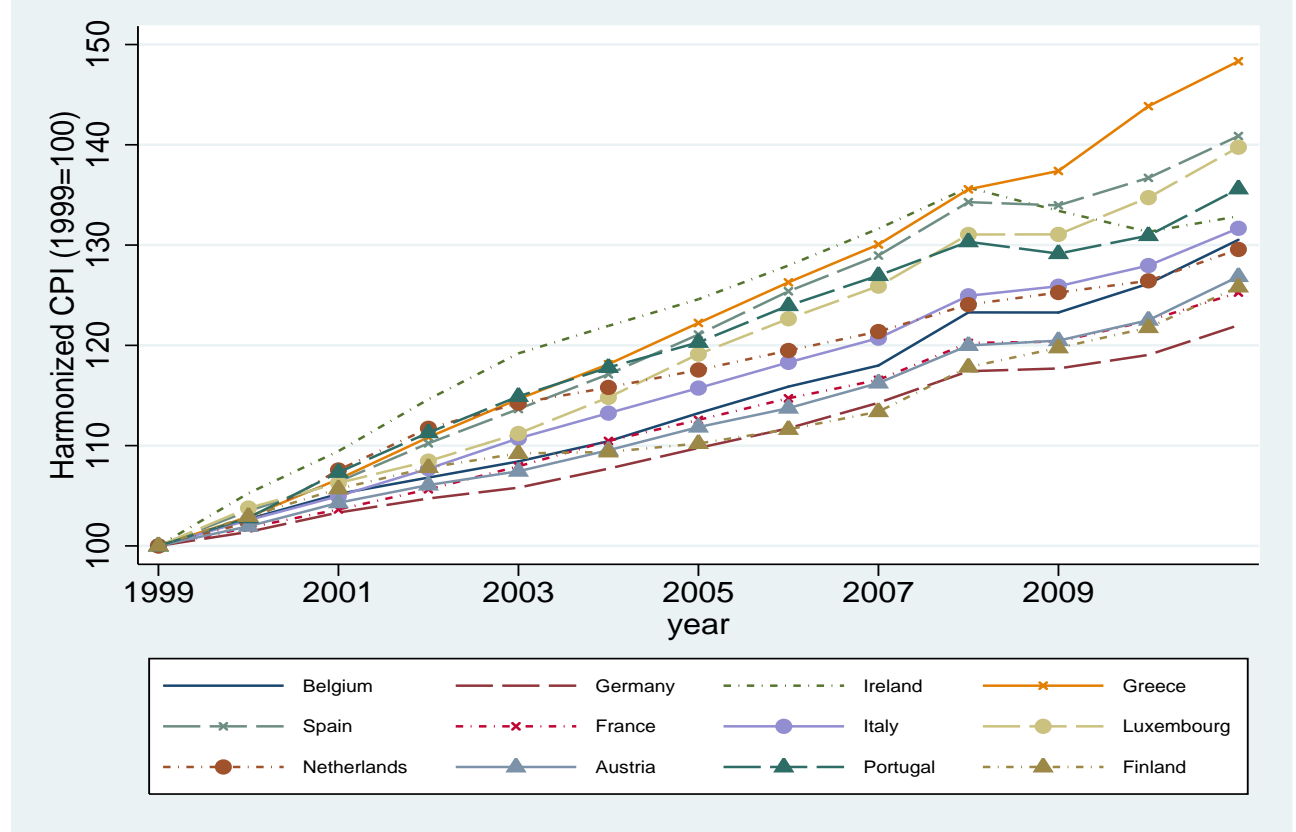

Source: Ameco.

fect competition in this sector - a key assumption of the BS model - can go a long way in explaining price divergences within the Euro area. Specifically, changes in product and labor market regulations are found able to magnify or offset the Balassa-Samuelson effect along the catching-up process. We construct a theoretical model that incorporates imperfect competition and employment protection in the classic BS framework. Our theoretical model predicts that market power in the nontradable sector and employment protection both affect the real exchange rate. Reduced competition in the nontradable sector or higher employment protection cause an appreciation of the real exchange rate. Based on econometric estimations for twelve European countries over 1985-2006, we finally quantify the contributions of the pure BS effect and those of product market regulations and employment protection in real exchange-rate variations. Through a counter-factual analysis, we find that, should product market regulations and employment protection have gradually converged to German levels over 1995-2006, the real exchange-rate appreciation observed in Mediterranean countries such as Greece, Portugal and Italy, would have been muted.

The remainder of the paper is organized as follows. Section 2 briefly surveys the literature on the BS effect. In Section 3, we present the theoret- 
Figure 2: Consumer price index in Euro area countries, tradables versus nontradables, 1999-2006 $(1999=100)$

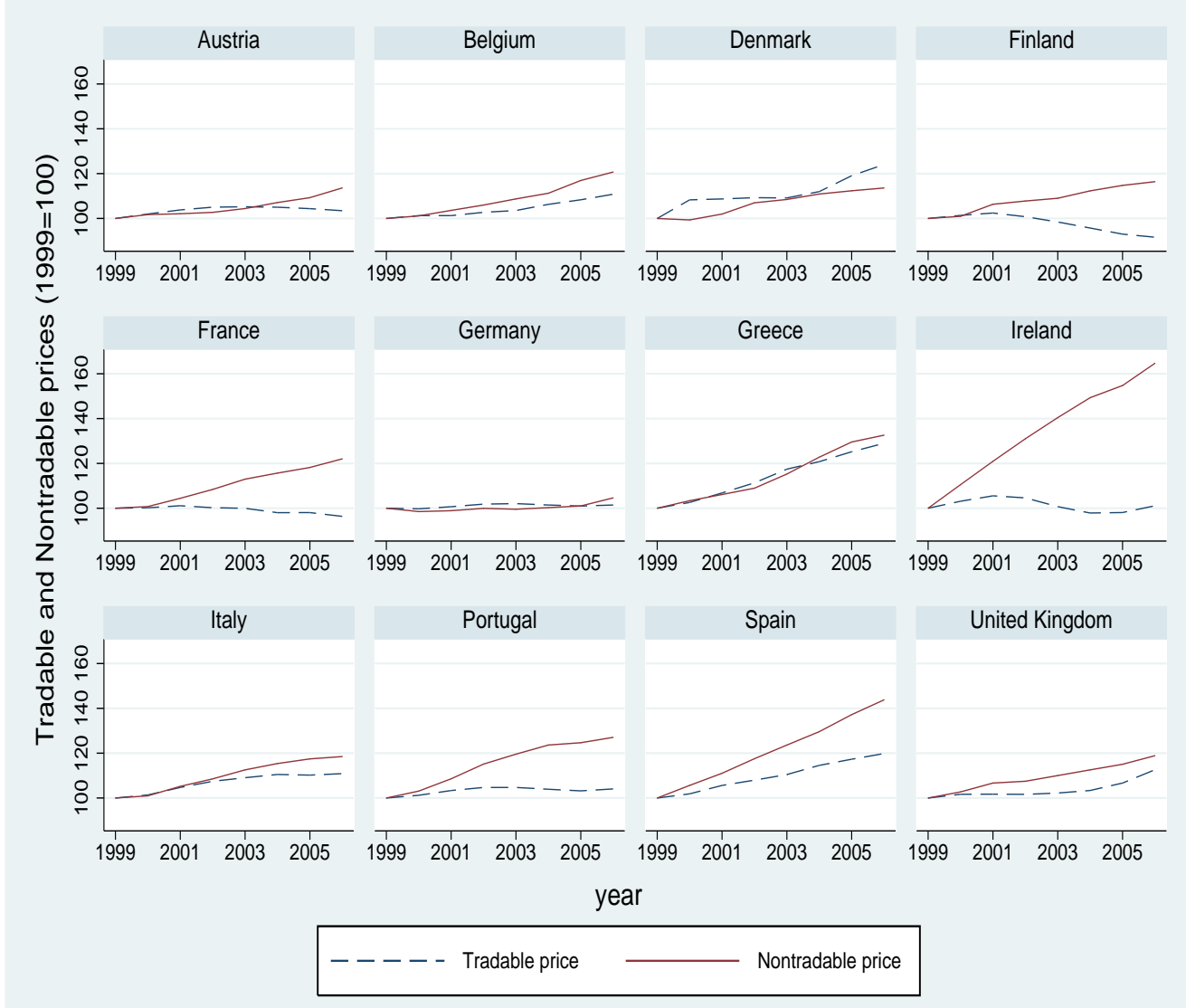

Source: EU KLEMS and own calculations. 
ical framework based on De Gregorio et al. (1994a). The data used in the estimations are described in Section 4. Section 5 presents the econometric strategy and reports the empirical estimation results. Section 6 presents a counter-factual exercise. Section 7 concludes.

\section{A brief overview of the literature}

The workhorse model for studying the evolution of nontradable prices in an open economy is the Balassa-Samuelson framework proposed by Balassa (1964) and Samuelson (1964). The original model features a small open economy producing two goods: a tradable good whose price is set at the international level (law of one price), and a nontradable one whose price is set at the country level, under perfect competition. Labour is the only production factor. It is assumed to be perfectly mobile across sectors but immobile internationally. In this setting, a rise in labour productivity in the tradable sector triggers a rise in wages in both the tradable and the nontradable sector. The latter, which does not benefit from the productivity gain, experiences a rise in its unit labour cost, which is accommodated through a price increase. On the whole, a productivity increase in the tradable sector leads to a real exchange-rate appreciation through the increase of the relative price of the nontradable good. This is the Balassa-Samuelson effect.

Several theoretical extensions of the BS setting have been proposed in the literature. ${ }^{4}$ Asea and Corden (1994), Asea and Mendoza (1994) and Turnovsky and Sen (1995) study the BS effect within a model with two production factors: labour and capital. Asea and Corden (1994) and Asea and Mendoza (1994) examine the implications of incorporating a demand side in the BS framework. These theoretical extensions corroborate that productivity differentials are at the root of relative price variations between tradable and nontradable goods, hence also between home and foreign goods. Turnovsky and Sen (1995) study the impact of demand shocks depending on relative sectoral capital intensities. Specifically, when the tradable sector is relatively intensive in nontradable capital, demand shocks cannot impact the real exchange rate; when the nontradable sector is relatively intensive in nontradable capital, demand shocks have only a transitory effect on the real exchange rate. In all cases, demand shocks appear unable to move the real exchange rate in the long run.

De Gregorio et al. (1994a) propose a two-sector, small open economy model in which nontradable goods are produced by monopolistically competitive firms and wages are determined by a centralized labor union. In this

\footnotetext{
${ }^{4}$ See Bahmani-Oskooee and Nasir (2005) for a review.
} 
model, shocks to productivity, consumer tastes, government expenditures and the price of tradables affect labor demand, wages and consequently the relative price of nontradables goods. More recently, Sheng and Xu (2011) extend the BS model to an environment with search unemployment. They show that matching efficiency influences the relationship between the relative price of nontradables and sectoral productivity: with limited labor market frictions, search unemployment is high and the BS hypothesis is violated. Both extentions of the BS model however assume market imperfections to be constant over time.

On the empirical side, there is a large literature that can be grouped into three strands. The first group consists of cross-sectional studies that generally show evidence of BS effect. The pioneer paper of Balassa (1964) falls in this group. Using data from twelve OECD countries, Balassa (1964) shows that countries with higher productivity in the tradable sector compared with the nontradable sector tend to diplay higher price levels. Subsequent papers such as Kravis and Lipsey (1983), Clague (1986, 1988) and Rogoff (1992) have confirmed this result, also based on cross-section data.

The second group of empirical studies relies on time-series data on a country-by-country basis. They generally support the BS effect (see Hsieh, 1982; Bahmani-Oskooee, 1992; Rogoff, 1992; Strauss, 1995, 1996).

The last group uses panel data techniques and also finds empirical evidence in favor of the BS hypothesis (see, e.g. Asea and Mendoza (1994), De Gregorio et al. (1994a,b), Strauss (1999), Bahmani-Oskooee and Nasir (2001) and Egert et al. (2003)). The empirical study in Sheng and Xu (2011) also falls in this last category. It provides empirical evidence of the relationship between sectoral productivity and the real exchange rate being influenced by labor market frictions.

Here we use the model of De Gregorio et al. (1994a), i.e. a BS model with monopolistic competition in the nontradable sector. ${ }^{5}$ Unlike De Gregorio et al. (1994a), however, we focus on variations in competition in the nontradable sector and changes in labor market friction as key drivers of the real exchange rate.

\section{Theoretical framework}

The economy is inhabited by a large number of identical households that live two periods. There are two goods in the economy: a tradable good denoted by $T$, and a nontradable one denoted by $N$. The tradable good is supplied

\footnotetext{
${ }^{5}$ We simplify the model by omitting government expenditures, the impact of which has been shown either neutral or ambiguous in the literature, see De Gregorio et al. (1994b).
} 
on an international, perfectly competitive market. As for the nontradable good, it is supplied on the local, imperfectly competitive market. Namely, we assume regulations in the nontradable sector to maintain a markup over the marginal price in this sector. Labour is the only production factor. The wage rate is set by a centralized bargaining arrangement between employers of the two sectors and trade unions.

\subsection{Household}

The representative household is assumed to maximize the following expected utility function:

$$
\underset{\left\{c_{t}^{T}, c_{t}^{N}\right\}_{t=1,2}}{\operatorname{ax}} \log \left[\left(c_{1}^{T}\right)^{\gamma}\left(c_{1}^{N}\right)^{1-\gamma}\right]+\beta \log \left[\left(c_{2}^{T}\right)^{\gamma}\left(c_{2}^{N}\right)^{1-\gamma}\right]
$$

subject to the following budget constraint:

$$
p_{1}^{T} c_{1}^{T}+p_{1}^{N} c_{1}^{N}+\frac{p_{2}^{T}}{1+r} c_{2}^{T}+\frac{p_{2}^{N}}{1+r} c_{2}^{N}=Y
$$

where $c_{t}^{T}$ and $c_{t}^{N}$ denote the consumption of the tradable and nontradable good, respectively, in period $t(t=1,2), p_{t}^{T}, p_{t}^{N}$ their respective prices, $\gamma \in[0,1]$ the share of the tradable good in household's total expenditure at each period, $\beta>0$ the subjective discount factor, $r$ the interest rate and $Y$ the intertemporal income. The budget constraint (2) implicitly assumes that there is no initial wealth (at the beginning of period 1) nor bequest (at the end of period 2). The intertemporal income is the discounted value of production in both sectors at both dates, $y_{t}^{T}$ and $y_{t}^{N}$ :

$$
Y=p_{1}^{T} y_{1}^{T}+p_{1}^{N} y_{1}^{N}+\frac{p_{2}^{T}}{1+r} y_{2}^{T}+\frac{p_{2}^{N}}{1+r} y_{2}^{N}
$$

The tradable good is assumed non-differentiated. Its price is set at the international level. In contrast, the nontradable good consists of differentiated varieties $j$, each being produced by a different monopolistically-competitive local firm. There is a continuum of such firms of measure 1. Denoting by $c_{t}^{N}(j)$ the consumption of the nontradable variety $j$ in period $t$, the composite consumption of the nontradable good is $c_{t}^{N}=\left(\int_{0}^{1} c_{t}^{N}(j)^{\frac{\theta-1}{\theta}} d j\right)^{\frac{\theta}{\theta-1}}$, where $\theta>1$ is the elasticity of substitution between nontradable varieties.

The solution of the household maximization program yields the following optimal intertemporal and intratemporal allocations: 


$$
\begin{gathered}
\frac{c_{2}^{T}}{c_{1}^{T}}=\beta(1+r) \frac{p_{1}^{T}}{p_{2}^{T}} \\
\frac{c_{t}^{T}}{c_{t}^{N}}=\frac{\gamma}{1-\gamma} \frac{p_{t}^{N}}{p_{t}^{T}} \text { for } t=1,2
\end{gathered}
$$

Equation (4) represents the Euler condition. It implies that spending on the tradable good $\left(p^{T} c^{T}\right)$ declines between period 1 and period 2 if $\beta(1+r)<$ 1 , increases in the opposite case and stays constant if $\beta(1+r)=1$. In turn, Equation (5) provides the optimal intratemporal allocation between tradable and nontradable goods. The distribution of the representative household's spending between the tradable and the nontradable good is constant over time, determined by the preference parameter $\gamma$. Equations (4) and (5) can finally be combined to recover the evolution of the consumption of the nontradable good between the two periods.

Combining equations (2) to (5), and remembering that by definition $c_{t}^{N}=$ $y_{t}^{N}$ for $t=1,2$, the intertemporal income can be rewritten in terms of tradable goods output as follows:

$$
Y=\frac{1}{\gamma}\left[p_{1}^{T} y_{1}^{T}+\frac{1}{1+r} p_{2}^{T} y_{2}^{T}\right]=\frac{Y^{T}}{\gamma} \text { where } Y^{T}=p_{1}^{T} y_{1}^{T}+\frac{1}{1+r} p_{2}^{T} y_{2}^{T}
$$

Denoting by $C_{t}$ total spending (of both goods) in period $t$, the optimum spending in each period is:

$$
\begin{gathered}
C_{1}=\frac{Y}{1+\beta}=\frac{Y^{T}}{\gamma(1+\beta)} \\
C_{2}=\frac{\beta(1+r) Y}{1+\beta}=\frac{\beta(1+r) Y^{T}}{\gamma(1+\beta)}
\end{gathered}
$$

The consumption of tradables (resp. nontradables) represents a fraction $\gamma($ resp. $(1-\gamma))$ of total consumption spending:

$$
c_{t}^{T}=\gamma \frac{C_{t}}{p_{t}^{T}} \text { and } c_{t}^{N}=(1-\gamma) \frac{C_{t}}{p_{t}^{N}}, t=1,2
$$

Given the level of nontradable consumption, household's demand for each variety of nontradable good is: ${ }^{6}$

$$
c^{N}(j)=\left(\frac{p^{N}(j)}{p^{N}}\right)^{-\theta} c^{N}=\frac{(1-\gamma) C}{p^{N}}\left(\frac{p^{N}(j)}{p^{N}}\right)^{-\theta}
$$

\footnotetext{
${ }^{6}$ Here we drop time subscripts for the sake of clarity.
} 
where

$$
p^{N}=\left(\int_{0}^{1} p^{N}(j)^{1-\theta} d j\right)^{\frac{1}{1-\theta}}
$$

Since there is no initial stock of external assets, the current-account balance in the first period is given by the excess supply of tradable goods:

$$
c a_{1}=y_{1}^{T}-c_{1}^{T}=\frac{\beta}{1+\beta}\left[y_{1}^{T}-\frac{p_{2}^{T}}{p_{1}^{T}} \frac{1}{(1+r) \beta} y_{2}^{T}\right]
$$

Therefore, if the price of tradable goods (determined exogenously) is fixed over the two-periods, and if the utility discount rate equals the world interest rate, the first period current-account is given by the difference in the level of output of tradable goods in the two periods.

Finally, the consumer price index is $p_{t}=\left(p_{t}^{T}\right)^{\gamma}\left(p_{t}^{N}\right)^{1-\gamma}$ so that $C_{t}=$ $p_{t} c_{t}=p_{t}^{T} c^{T}+p_{t}^{N} c_{t}^{N}$ where $c_{t}=\gamma^{-\gamma}(1-\gamma)^{-(1-\gamma)}\left(c_{t}^{T}\right)^{\gamma}\left(c_{t}^{N}\right)^{1-\gamma}$ being the aggregate consumption.

\section{$3.2 \quad$ Firms}

In both sectors, production uses labor as a single input. Labor is supplied inelastically by the representative household, but there is perfect labor mobility across the two sectors, ensuring a single wage is set, $W$.

\subsubsection{Tradable sector}

Production of the tradable good is subject to decreasing returns to scale:

$$
y^{T}=a^{T}\left(l^{T}\right)^{\alpha}
$$

where $a^{T}$ is a technology, productivity-enhancing factor, $l^{T}$ denotes labor in the tradable sector, and $0<\alpha<1$. The price of the tradable good is set at international level. Profit maximization then yields:

$$
\alpha a^{T}\left(l^{T}\right)^{\alpha-1}=\frac{W}{p^{T}}
$$

Therefore, equilibrium output in the tradable sector is given by:

$$
y^{T}=\left(a^{T}\right)^{1 /(1-\alpha)}\left(\frac{\alpha p^{T}}{W}\right)^{\alpha /(1-\alpha)}
$$




\subsubsection{Nontradable sector}

In the nontradable sector, there is a continuum of individual producers under monopolistic competition. We assume constant returns to scale for each producer. The production of each variety is thus given by:

$$
y^{N}(j)=a^{N} l^{N}(j)
$$

where $l^{N}(j)$ denotes labor used to produce variety $j$, and $a^{N}$ represents mean and marginal productivity, which is constant.

Each firm $j$ maximizes its profit accounting for its own demand function subject to its technological constraint. At equilibrium, the demand for each nontraded variety equals its production: $y^{N}(j)=c^{N}(j)$. Hence, each producer $j$ has the following maximization program:

$$
\underset{l^{N}(j)}{\operatorname{Max}} p^{N}(j) y^{N}(j)-W l^{N}(j)
$$

subject to $y^{N}(j)=a^{N} l^{N}$ and $y^{N}(j)=\left(\frac{p^{N}(j)}{p^{N}}\right)^{-\theta} c^{N}$.

The solution of this program is:

$$
p^{N}(j)=p^{N}=\frac{\theta}{\theta-1} \frac{W}{a^{N}}=\mu \frac{W}{a^{N}}
$$

where $\mu=\theta /(\theta-1)$ is the markup in the nontradable sector.

Given that $p^{N}(j)=p^{N}$, the equilibrium output of nontradable sector can easily be recovered:

$$
y^{N}=c^{N}=\frac{(1-\gamma) Y^{T}}{\gamma(1+\beta) p^{N}}=\frac{(1-\gamma) a^{N} Y^{T}}{\gamma \mu(1+\beta) W}
$$

\subsection{Labor union}

Total labor demand is given by $L^{d}=l^{T}+l^{N}$. From Equation (14), we get labour demand in the tradable sector:

$$
l^{T}=\left(\frac{\alpha a^{T} p^{T}}{W}\right)^{1 /(1-\alpha)}
$$

From equations (16) and (19) and since $y^{N}=(1 / \mu) a^{N} l^{N}$, we get labour demand in the nontradable sector:

$$
l^{N}=\int_{0}^{1} l^{N}(j) d j=\mu y^{N} / a^{N}=\frac{(1-\gamma) Y^{T}}{\gamma(1+\beta) W}
$$


So, total labour demand is given by:

$$
L^{d}=l^{T}+l^{N}=\left(\frac{\alpha a^{T} p^{T}}{W}\right)^{1 /(1-\alpha)}+\frac{(1-\gamma) Y^{T}}{\gamma(1+\beta) W}
$$

Denoting by $w$ the consumption real wage $(w=W / p)$, Equation $(22)$ can be re-written as follows:

$$
L^{d}=l^{T}+l^{N}=\left(\frac{\alpha a^{T} p^{T}}{w p}\right)^{1 /(1-\alpha)}+\frac{(1-\gamma) Y^{T}}{\gamma(1+\beta) w p}
$$

Like De Gregorio et al. (1994a), we assume that the real wage $w$ is determined by a centralized labor union. The objective of the union is to minimize a quadratic loss function of the deviations of employment $(L)$ and the real wage $(w)$ from their targets. This problem is:

$$
\underset{w}{\operatorname{Min}}(L-\bar{L})^{2}+\lambda(w-\bar{w})^{2}
$$

subject to

$$
L=L^{d}(w)
$$

where $\bar{L}$ and $\bar{w}$ are the employment and real wage targets, respectively, and $\lambda>0$ measures the relative weight given to wages (relative to employment) by the union. It is assumed that the union only sets the real wage of the current period, after observing current and anticipated values of productivities and markups.

From Equation (23), it can be seen that labor demand $L^{d}$ is nonlinear in $w$. Following De Gregorio et al. (1994a), we use a linear first-order Taylor approximation of $L^{d: 7}$

$$
L^{d}=\underset{+}{L_{0}}\left(a_{+}^{T}, a_{+}^{N}, p_{-}^{T}, \mu\right)-\epsilon w
$$

where $a^{T}, a^{N}, p^{T}$ and $\mu$ affect $L_{0}$ with the same sign as they affect the labor demand and $\epsilon>0$. This formulation is similar to De Gregorio et al. (1994a), except for the markup $\mu$ that here is allowed to change.

The solution of union's program yields the following equilibrium real wage:

\footnotetext{
${ }^{7}$ The first-order Taylor approximation of $(23)$ around $w_{0}$ is given by $L^{d}(w)=L^{d}\left(w_{0}\right)+$ $\left(w-w_{0}\right) \partial L^{d}\left(w_{0}\right) / \partial w=L_{0}+\epsilon w$ where $\partial L^{d}(w) / \partial w=\frac{1}{(1-\alpha) w}\left(\frac{\alpha a^{T} p^{T}}{p w}\right)^{1 /(1-\alpha)}-\frac{(1-\gamma) Y^{T}}{\gamma(1+\beta) p w^{2}}$, $L_{0}=L^{d}\left(w_{0}\right)-w_{0} \partial L^{d}\left(w_{0}\right) / \partial w$ and $\epsilon=-\partial L^{d}\left(w_{0}\right) / \partial w$. Like De Gregorio et al. (1994a), we neglect here the effect of labor demand parameters on $\epsilon$.
} 


$$
w=\frac{\lambda}{\lambda+\epsilon^{2}} \bar{w}+\frac{\epsilon}{\lambda+\epsilon^{2}}\left(L_{0}-\bar{L}\right)
$$

If the values of $a^{T}, a^{N}, p^{T}, \mu, \bar{w}$ and $\lambda$ are the same in period 1 as in period 2 , then, at equilibrium, the real wage can be written as follows:

$$
w=\underset{+}{w}\left(a_{+}^{T}, a_{+}^{N}, p_{+}^{T}, \mu, \bar{w}, \lambda_{+}\right)
$$

A permanent rise in productivity in the tradable or in the nontradable sector raises permanent income, hence labor demand and the real wage. A permanent fall in the markup in the nontradable sector sector has the same impact qualitatively as a rise in productivity. A rise in the price of the tradable amounts to positive shock on terms-of-trade, increasing the permanent income of households, hence the labor demand by the firms and the equilibrium real wage. Finally, labor market frictions have a positive, direct impact on the real wage set by the union. Note that both the target wage $\bar{w}$ and its weight $\lambda$ in the unions' loss function (the relative power of insiders vis-à-vis outsiders and firms) interact in the determination of the real wage.

We now consider a change in the parameters determining the real wage over time. Specifically, Equation (29) shows how the parameters of both periods affect the real wage in period 1 .

$$
\begin{gathered}
w_{1}=w\left(a_{1}^{T}, a_{2}^{T}, a_{1}^{N}, a_{2}^{N}, P_{1}^{T}, P_{2}^{T}, \mu_{1}, \mu_{2}, \bar{w}_{1}, \lambda_{1}\right) \\
++_{+}++_{+}
\end{gathered}
$$

For instance, an expected fall in the markup $\mu$ in period 2 raises the real wage already in period 1 . The reason is that a fall in $\mu_{2}$ increases permanent income, hence labour demand in both periods. The rise in labor demand, hence in the real wage, is more limited in period 1 , where it is driven by a demand effect, than on period 2, where firms in the nontradable sector do experiment the reduced markup. As for labor market frictions, we follow the literature in assuming that they do not affect wages through their impact on the permanent income. This assumption ensures that reduced labor market frictions have a negative impact on the real wage. Another implication is that only current labor market frictions affect the real wage.

The nominal wage can be recovered by noting that $W=w p$ :

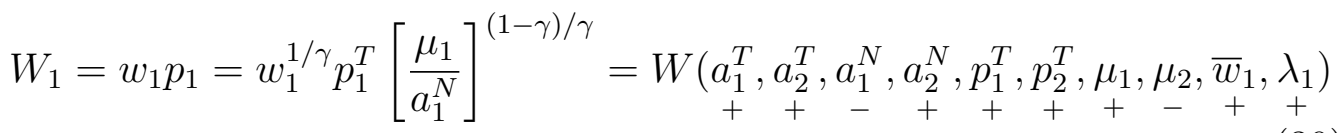

A fall in $\mu$ (or a rise in $a^{N}$ ) has opposite effect on the nominal wage of period 1 depending on whether the shock occurs in period 1 or in period 
2. In the latter case, the demand for nontradables increases in period 1 , for a given supply. Hence the price of nontradables increases, and so does the nominal wage (which increases more than prices). In the former case, the rise in the demand for nontradables in period 1 is more limited than the rise in the supply. The price of nontradables falls, and so does the nominal wage (which falls by less than prices).

\subsection{Balassa-Samuelson effect with a union and product market regulations}

As shown in the previous subsection, a permanent decrease in $\mu, \bar{w}$ or $\lambda$ depresses the price of nontradables, hence triggers a real exchange rate depreciation. In turn, anticipating in period 1 a product market deregulation in period 2 leads to a rise in the nontradable price in period 1 . The real exchange rate appreciates in period 1 and depreciates in period 2, when the supply of nontradables rises. This dynamic effect is absent in the case of an anticipated deregulation of the labor market.

Because it affects tradable output equally in the two periods, and since the tradable price is fixed, a permanent deregulation of the nontradable sector in period 1 has no impact on the current account (to the extent that the utility discount rate equals the world interest rate): $\left.c a=\beta /(1+\beta) .\left(y_{1}^{T}-y_{2}^{T}\right)\right)$. However, an anticipated product market deregulation in period 2 has a negative impact on the current account in the first period and a positive one in the second one, when tradable output actually increases.

We are now interested in the long-term relationship between deregulation of product and labor markets and the real exchange rate. As argued above, a deregulation of the nontradable sector depreciates the real exchange rate, if not in the short run (when anounced), at least in the long run (when implemented). As for the deregulation of the labor market, it has no impact on the real exchange rate when anounced but depreciates the real exchange rate in the long run (when implemented). Denoting foreign variables by an $F$ subscript, and assuming the same share of tradables $\gamma$ for each country, under the law of price for the tradable sector, the bilateral real exchange rate between the home and the foreign country is given by:

$$
R E R=\frac{p}{p_{F}}=\left(\frac{p^{T}}{p_{F}^{T}}\right)^{\gamma}\left(\frac{p^{N}}{p_{F}^{N}}\right)^{(1-\gamma)}=\left(\frac{p^{N}}{p_{F}^{N}}\right)^{(1-\gamma)}
$$

Assuming that the home and the foreign countries are identical except for productivity and market regulations, we get: 


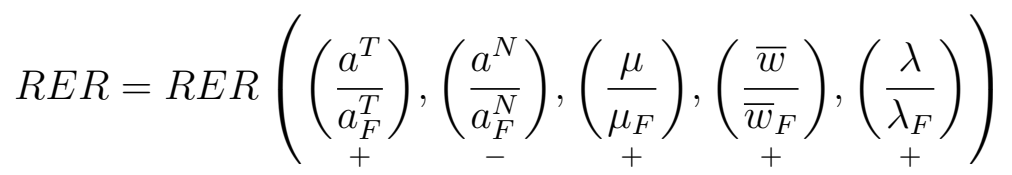

Equation (32) encapsulates the traditional BS effect (first two terms). Here, however, market power in the nontradable sector $(\mu)$ and union demands in terms of real wages $(\lambda, \bar{w})$ also affect the real exchange rate. Following Blanchard and Giavazzi (2003), we consider that anti-competition regulations (such as price controls or vertical integration, see Conway et al. (2006)) tend to reduce the elasticity of substitution $\theta$, hence to increase the markup $\mu$. Our model does not explicitly account for firm entry, hence entry costs are not identified in the model. However, restrictions to entry can also be thought to increase the elasticity of substitution, hence to reduce the markup.

Assuming, as in the literature, that productivity grows faster in the tradable sector than in the nontradable one, the empirically testable model is given by:

$$
R E R=R E R\left(\left(\frac{G D P}{G D P_{F}}\right),\left(\frac{P M R}{P M R_{F}}\right),\left(\frac{E P}{E P_{F}}\right)\right)
$$

$G D P$ is the real GDP per capita. $P M R$ stands for the product market regulation index $(\mu)$. Finally, EP represents an index of employment protection that refers to $\lambda$ and $\bar{w}$, where $\lambda$ and $\bar{w}$ interact.

\section{Data}

We consider annual data for twelve European countries: Austria, Belgium, Denmark, Finland, France, Germany, Greece, Ireland, Italy, Portugal, Spain and United Kingdom. These countries are selected based on data availability to get a balanced panel. We focus on EU countries for two reasons. First, the single market makes the law of one price more likely to apply in this region than in any other in the world. Second, we want to use our framework to shed some light in observed price divergences over the monetary-union period. Data cover the period 1985-2006.

The product market regulations (PMR) index in the nontradable sector is computed as a weighted average of product market regulations in individual sectors, weights being given by the shares in aggregate nontradable value-added. Data on sectoral regulations are collected from the OECD (OECD, 2011). The latter converts qualitative features such as laws and 
regulations into quantitative indices. More specifically, the index measures the "knock-on" effects (i.e. the costs) of anti-competitive regulations in selected non-manufacturing sectors and in sectors of the economy that heavily rely on non-manufacturing inputs (see Conway et al. (2006) for more details). In line with previous studies (De Gregorio et al., 1994b), we consider the following sectors as tradable: Agriculture, hunting, forestry and fishing; Mining and quarrying; Total manufacturing; Transport, storage and communication. The following sectors are classified as nontradable: Electricity, gas and water supply; Construction; Wholesale and retail trade; Hotels and restaurants. Data on sectoral value-added are taken from EUKLEMS database.

The employment protection index (EP) is also collected from the OECD. It refers to all types of employment protection measures, whether grounded primarily in legislation, court rulings, collectively bargaining conditions of employment or customary practice (See Venn (2009)). Like the PMR index, the EP index scales quantitatively information that is mostly qualitative.

The real exchange rate and the real GDP per capita are recovered from the Penn World Table version 7.0 (PWT 7.0, Heston et al., 2011). Following Frankel (2006) and Rodrik (2008), we use the Penn World Table comparative prices as the real exchange rate. These comparative prices have the advantages of being internationally comparable in level. As in Frankel (2006) and Rodrik (2008), we use GDP per capita at 2005 constant prices as a measure of productivity.

We need to select one country of the sample as "foreign". We pick up the largest country, namely Germany and relate all variables to the same variables in Germany. ${ }^{8}$ This choice also fits the debate on relative price divergences within the euro area since monetary unification. In the econometric estimation, the choice of a reference country is neutral since all estimations are performed in logarithms.

Figure 3 displays the dynamics of real exchange rates and real GDPs per capita. This figure highlights the standard BS effect, i.e., real exchange rate and real income are positively correlated, although the real exchange rate is more volatile especially before European Monetary Unification (EMU) and in the UK.

\footnotetext{
${ }^{8}$ Changing the reference country does not alter the main conclusion of our study, which emphasizes the role of PMR, although the impact of EP apppears more fragile. The results are available from the authors.
} 
Figure 3: Real exchange rate and real GDP per capita, relative to Germany

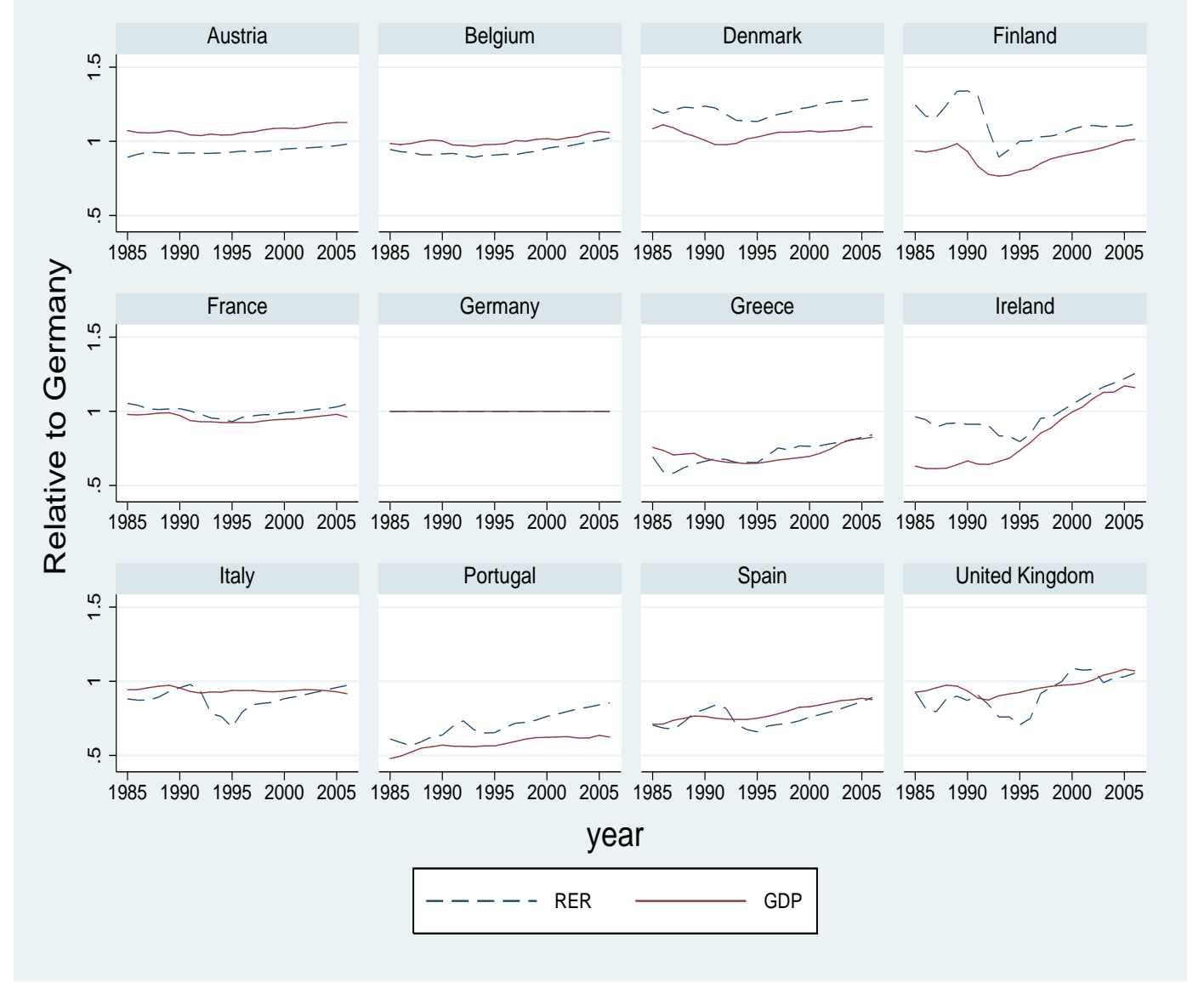

Source: Penn World Table version 7.0 and own calculations. 
Figure 4: Product market regulations (1985, 1995, 2006)
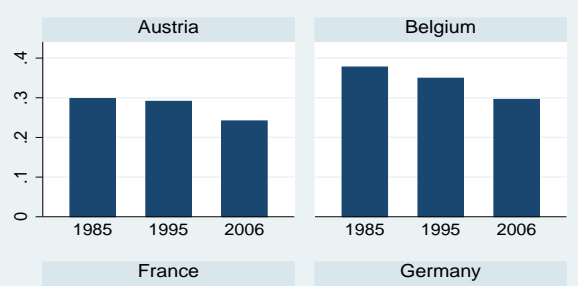

Denmark Finland

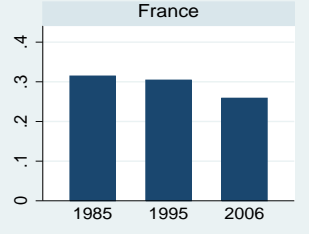

Germany
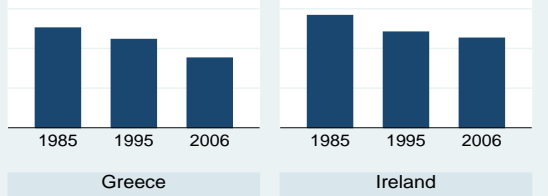

Italy
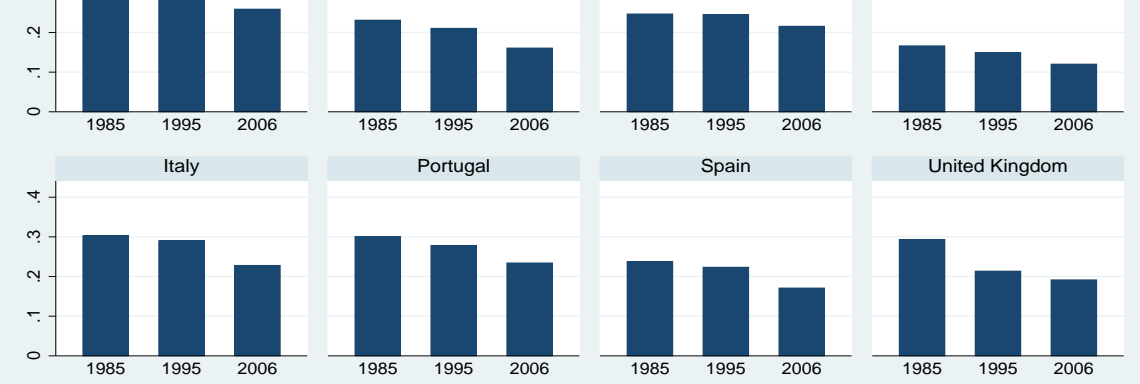

Portugal

Spain

United Kingdom

Source: OECD database and own calculations.

Figure 5: Employment protection (1985, 1995, 2006)

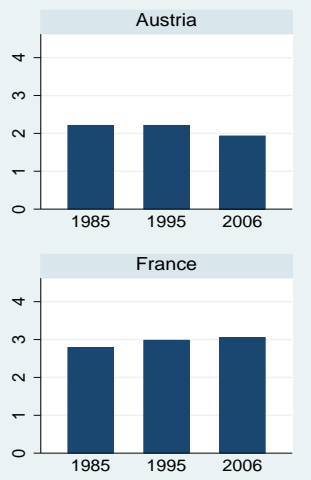

Belgium

Denmark

Finland
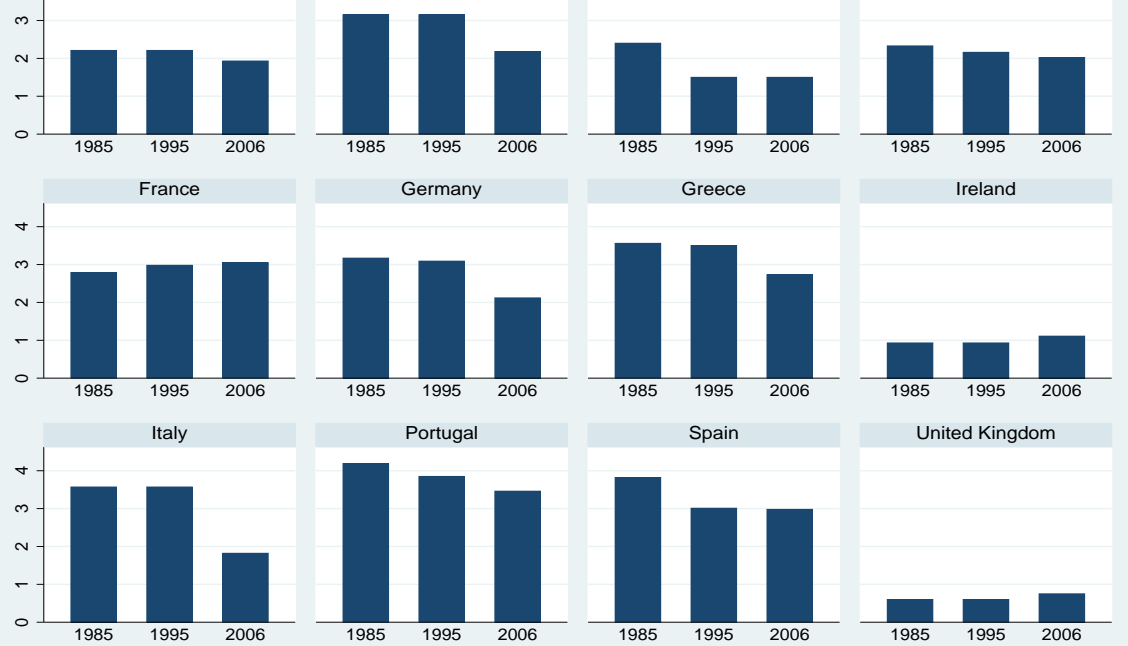

Germany

Greece

Ireland
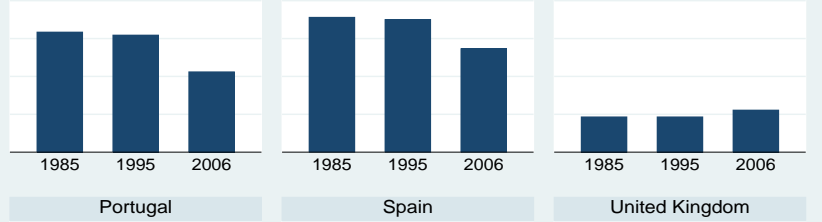

Portugal
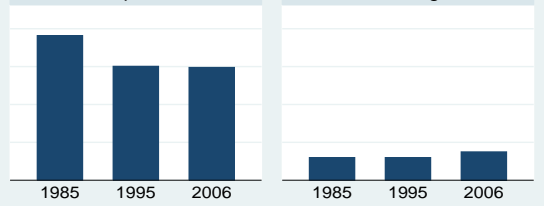

Source: OECD database and own calculations. 
Figure 6: Real exchange rates and market regulations, relative to Germany

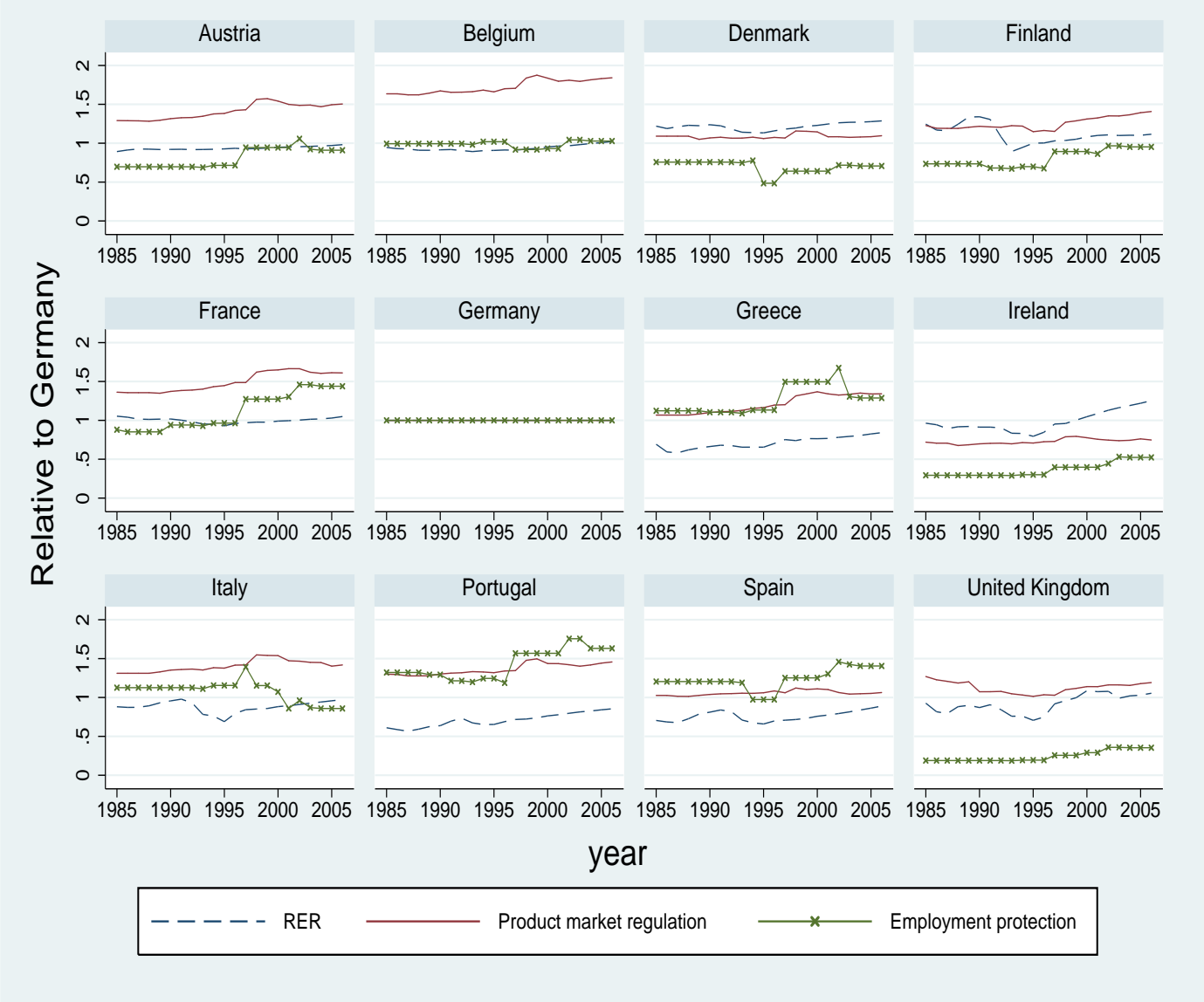

Source: OECD database and own calculations. 
Figures 4 and 5 report PMR and EP indices in 1985, 1995 and 2006, successively. ${ }^{9}$ In all the countries of the sample the PMR tends to decline over time (Figure 4), albeit at different paces. The decline is relatively slow in Greece, and delayed in Italy and France. In 2006, all countries but Ireland display tighter regulations than Germany, and in most of them, the gap to Germany has increased since the mid-1990s.

Conversely, not all countries display a downward trend for EP: EP increases over time in France while it stays constant at a very low level in Ireland and the UK (Figure 5). In 2006, Germany appears in a median situation concerning EP.

Figure 6 compares the dynamics of the real exchange rate to those of PMR and EP indices (relative to Germany). In most countries, the real exchange rate seems positively correlated to both indices.

\section{Econometric estimation}

In this section, we intend to test our theoretical result that product market regulations in the nontradable sector, together with employment protection, impact the real exchange rate on the top of the traditional BS effect. More specifically, we intend to estimate the long-term relationship (33) through panel cointegration.

\subsection{Panel unit root and cointegration tests}

We first study the presence of unit roots in our series based on the panel unit root tests proposed by Im, Pesaran and Shin (2003) (IPS) and Pesaran (2007) Cross-sectionally Augmented Dickey-Fuller (CADF). The Pesaran CADF allows to take account of the cross-sectional dependence since it is based on Dickey-Fuller type regressions augmented with the cross-section averages of lagged levels and first differences of the individual series. The results of these tests are reported in Table 1. At conventional levels of significance, all series are found non-stationary in level, but stationary in first differences (see Table $1)$.

We then test for cointegration between the variables using the approach proposed by Westerlund (2007). Specifically, we test whether there exists error correction for individual panel members or for the panel as a whole. This approach is flexible as it allows for heterogeneous specifications of both the long and short run parts of the error correction model, based on the data. Furthermore, the Westerlund panel cointegration test accounts for

\footnotetext{
${ }^{9}$ Intermediate years are available but skipped here to save space.
} 
Table 1: Panel unit root tests

\begin{tabular}{l|cc|cc}
\hline \hline Variable & \multicolumn{2}{|c}{ Level } & \multicolumn{2}{c}{ First difference } \\
& IPS & CADF & IPS & CADF \\
\hline $\ln R E R_{i}$ & 0.240 & -2.193 & -7.069 & -3.089 \\
& $(0.595)$ & $(0.674)$ & $(0.000)$ & $(0.000)$ \\
$\ln \left(\frac{G D P_{i}}{G D P_{G E R}}\right)$ & -0.991 & -2.356 & -4.232 & -2.626 \\
$\ln \left(\frac{P M R_{i}}{P M R_{G E R}}\right)$ & $(0.161)$ & $(0.449)$ & $(0.000)$ & $(0.002)$ \\
$\ln \left(\frac{E P_{i}}{E P_{G E R}}\right)$ & 1.218 & -1.871 & -9.865 & -3.155 \\
& $(0.888)$ & $(0.945)$ & $(0.000)$ & $(0.000)$ \\
& 0.192 & -1.542 & -12.069 & -2.323 \\
\hline \hline
\end{tabular}

Note: IPS denotes $W_{t}-$ bar of Im, Pesaran and Shin (2003) panel unit root test and CADF is Cross-sectionally Augmented Dickey-Fuller test statistic of Pesaran (2007). The two tests have the null hypothesis of a unit root. P-values are in parenthesis. Country-specific intercept and time trend were included in both tests. Source: Authors' calculations.

Table 2: Panel cointegration tests (Westerlund)

\begin{tabular}{lcc}
\hline \hline & Test Stat. & P-value \\
\hline$G_{\tau}$ & $-2.339^{* *}$ & 0.030 \\
$G_{\alpha}$ & $-6.565^{* *}$ & 0.040 \\
$P_{\tau}$ & $-6.668^{*}$ & 0.055 \\
$P_{\alpha}$ & $-5.735^{*}$ & 0.070 \\
\hline \hline
\end{tabular}

Notes: Null hypothesis of no-cointegration. Pvalues are obtained from 1000 bootstrap replications. $*, * *, * * *$ denotes the significance at $10 \%, 5 \%$ and $1 \%$ level, respectively.

Source: Authors' calculations. 
cross-section dependence since the robust critical values can be computed through bootstrapping. The case for cross-section dependence is especially compelling in our case where shocks to the German economy affect all individual observations simultaneously.

The null hypothesis of Westerlund's tests is the absence of cointegration. The $G_{\alpha}$ and $G_{\tau}$ statistics test whether there exits cointegration for at least one individual panel member. The $P_{\alpha}$ and $P_{\tau}$ statistics pool information over all the individual panel members to test whether there exits cointegration for the panel as a whole. As reported in Table 2, the four tests reject the null hypothesis of no cointegration at least at the 10 percent level. We conclude that there is evidence of cointegration.

\subsection{Long-run relationship}

Regarding the estimation of the long-run relationship, two approches have been proposed in the literature that both deal with serial correlation and the endogeneity of the regressors. The first one is the Fulled Modified Ordinary Least Squares (FMOLS) technique proposed by Phillips and Hansen (1990) that provides optimal estimates of cointegrating regressions by modifying least squares. The second technique, the Dynamic Ordinary Least Squares (DOLS), provided by Saikkonen (1991) and Stock and Watson (1993) consists in using the leads and lags of the differenced endogenous variables as regressors. An extension to a panel framework was proposed by Pedroni (2001) and Phillips and Moon (1999) for the FMOLS, and by Mark and Sul (2003), for DOLS. In this paper, we use the panel DOLS proposed by Mark and Sul (2003), since Kao and Chiang (2001) show that DOLS outperforms both OLS and FMOLS estimators in estimating cointegrated panel regressions.

The empirical model corresponding to equation (33) is:

$$
\begin{aligned}
\ln R E R_{i t}=\beta \ln \left(\frac{G D P}{G D P_{G E R}}\right)_{i t}+\phi_{P M R} \ln \left(\frac{P M R}{P M R_{G E R}}\right)_{i t} & +\phi_{E P} \ln \left(\frac{E P}{E P_{G E R}}\right)_{i t} \\
& +u_{i}+\lambda_{i t}+\theta_{t}+\epsilon_{i t}
\end{aligned}
$$

where $G E R$ stands for Germany, $u_{i}$ is a country-specific effect, $\lambda_{i t}$ is country-specific time trend, and $\theta_{t}$ is a common-time effect that serves to account for cross-sectional dependence.

The PDOLS procedure consists in estimating Equation (34) by instrumental variables using leads and lags of differenced endogenous variables as instruments. By Monte Carlo experiments, Mark and Sul (2003) show that the panel dynamic OLS provides much more precise estimates compared to the corresponding single-equation counterparts even for a small number of cross-sectional units. 
Table 3: Panel cointegration estimates of the Balassa-Samuelson effect with market regulations

\begin{tabular}{lcccc}
\hline \hline & \multicolumn{3}{c}{$\begin{array}{c}\text { Dependent variable: } \\
\text { No common trend }\end{array}$} & Common trend \\
\hline $\ln \left(\frac{G D P}{G D P_{G E R}}\right)$ & $0.864^{* * *}$ & $0.611^{* * *}$ & $0.400^{* * *}$ & $0.340^{* * *}$ \\
& $(0.207)$ & $(0.115)$ & $(0.193)$ & $(0.118)$ \\
$\ln \left(\frac{P M R}{P M R_{G E R}}\right)$ & & $0.510^{* * *}$ & $0.656^{* * *}$ \\
& $(0.161)$ & $(0.191)$ \\
$\ln \left(\frac{E P}{E P_{G E R}}\right)$ & $0.233^{* * *}$ & $0.184^{* * *}$ \\
& $(0.061)$ & $(0.071)$ \\
\hline \hline Note: Standard errors, written in parenthesis, are based on \\
Andrews and Monahan (1992) pre-whitening method. *** denotes \\
the significance at 1\% level.
\end{tabular}

Table 3 reports the estimation of the BS effect with product market regulations and employment protection. For purpose of comparison to the standard BS effect, we also estimate the model without market regulations. For robustness, a first estimation is implemented with individual fixed effects and individual trends, while the second estimation adds a common trend with individual fixed effects and individual trends. The results in Table 3 show that all the explanatory variables (real GDP per capita, product market regulations index in the nontradable sector and employment protection index, all being relative to Germany) have the expected sign and are significant at the $1 \%$ level. In particular, the results highlight the standard BS effect, i.e., an increase in country differential GDP per capita leads to an appreciation of the real exchange rate relative to Germay. The impact of a one-percent growth differential ranges from a 0.34 to 0.86 percent relative exchange-rate appreciation, depending on the specification. ${ }^{10}$ Interestingly, introducing market regulations tends to depress the coefficient on the BS effect.

A rise in either the PMR or the EP index (relative to Germany) leads the real exchange rate to appreciate, the effect being stronger for PMR than for EP. Indeed, a one-percent increase in the PMR index (relative to Germany) triggers a 0.51 to 0.66 percent price increase relative to Germany. As evidenced in Figure 4, the German PMR index fell by 24\% from 1995 to 2006 but only by $12 \%$ in Greece over the same period. Hence the Greek PMR

\footnotetext{
${ }^{10}$ This range stays consistent with the basic BS framework with perfect competition, where the coefficient on the BS effect is equal to the share of nontradables in the economy.
} 
Figure 7: Counterfactual analysis

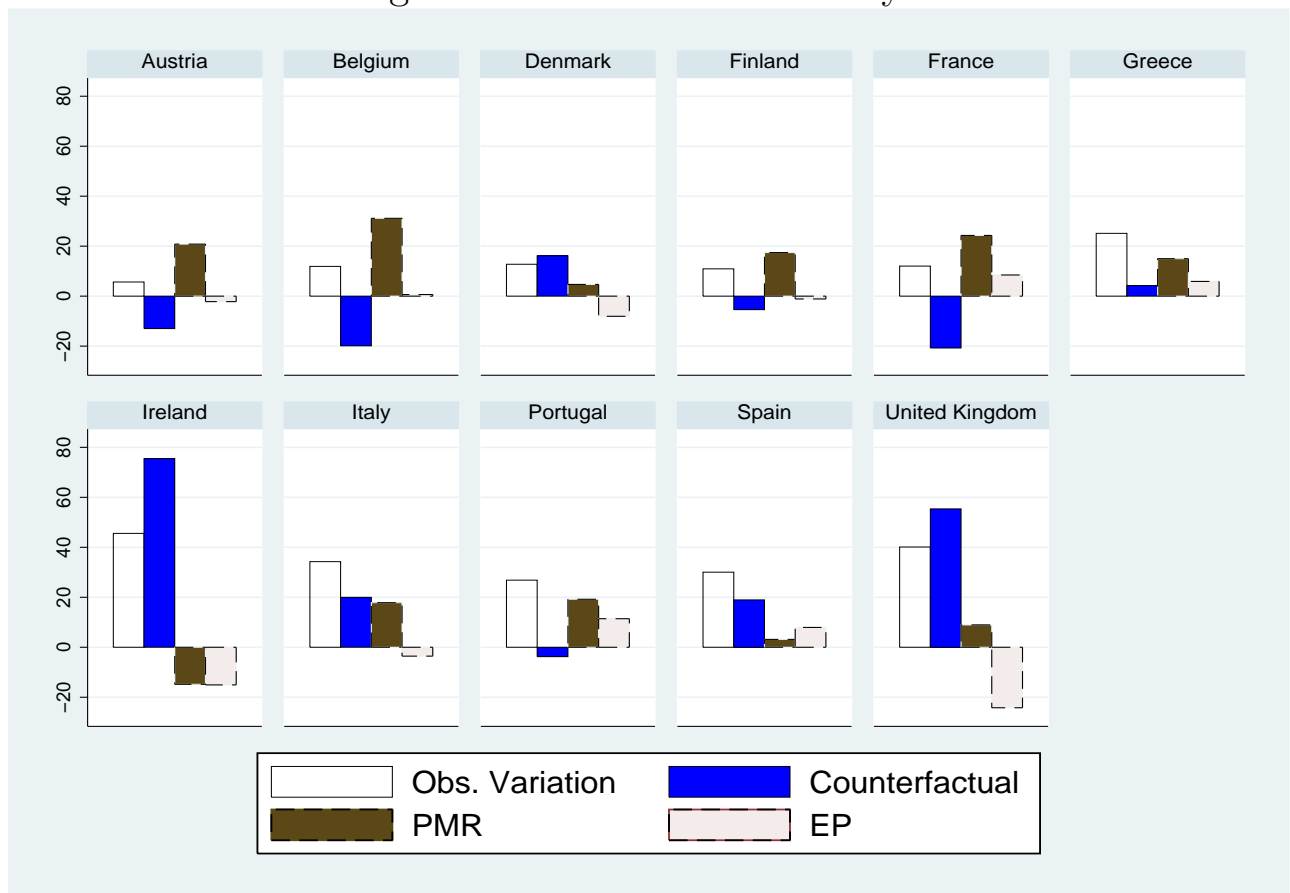

Note: All variables are relative to Germany.

increased by $12 \%$ relative to Germany which, according to our estimation, can explain a relative price increase of 6 to 8 percent.

In turn, a 1 percent increase in relative employment protection triggers a 0.18 to 0.23 percent relative price increase. Looking back to Figure 5, we see that between 1995 and 2006, the EP index fell by 31\% in Germany and by $22 \%$ in Greece, hence the Greek EP index increased by $11 \%$ relative to Germany. According to our estimations, this can explain an additional 2 to 3 percent increase in the relative price of Greece. Adding up the effect of the PMR and that of the EP index, we get a 10-12 percent real exchange rate appreciation in Greece relative to Germany between 1995 and 2006, hence a large part of the observed 25 percent appreciation. We conclude that product and employment market regulations are far from anecdotal in explaining relative price variations within the Euro area. The next section proposes a counterfactual analysis to further measure the impact of these regulations. 


\section{Counterfactual analysis}

To futher quantify the contributions of product and labor market regulations in real exchange-rate variations, we now conduct a counterfactual analysis. We consider a linear convergence of product and labor market regulations to their corresponding levels of Germany from 1995 to 2006. The results are displayed in Figure 7. For each country, the first bar reports the observed variation in the real exchange between 1995 and 2006. The second one shows the counterfactual variation in the real exchange rate under convergence of market regulations. The third and fourth bars report the contribution of PMR and EP, respectively, to the difference between the first two bars.

The charts in Figure 7 indicate that, under convergence of market regulations, real exchange appreciations observed in Greece, Italy and Spain would have been much reduced, while the real exchange rate would have even slightly depreciated (relative to Germany) in Austria, Belgium, Finland, France and Portugal. On the contrary, in Denmark, Ireland and the UK, the real exchange rate would have appreciated more under convergence. In most countries, the main contribution in these counterfactual results is the evolution of PMR. This is especially the case in Belgium, France, Greece, Italy and Portugal where the convergence of the PMR to the German level would have been enough to erase any real exchange-rate appreciation. The contribution of EP is smaller but still important for France, Greece and Portugal. In Ireland, convergence of both PMR and EP to German levels would have almost doubled the observed real exchange-rate appreciation over the period. This is because both indicators are much lower in this country than in Germany.

\section{Conclusion}

We have analyzed how product market regulations in nontradable sectors and employment protection influence the dynamics of the real exchange rate. The theoretical framework incorporates imperfect competition and employment protection in the classical Balassa-Samuelson model. Subsequently, we have conducted an econometric estimation for European countries over 1985-2006, confirming the prediction of the theoretical model that product market regulations in the nontradable sector and employment protection tend to inflate the real exchange rate. Finally, we have proposed a counter-factual exercise to quantify further the role of product market regulations and employment protection.

Our results confirm the role played by both types of market regulations 
in the evolution of intra-European real exchange rates. This effect is quantitatively large as it explains most of observed real exchange-rate appreciation vis-à-vis Germany between 1995 and 2006 for several countries of the Euro area. We conclude that structural reforms may be a powerful driver of relative price adjustment within the Euro area. Although they would not directly impact on external competitiveness (since their influence goes through the price of nontradables), they would raise output and labor demand in both sectors. 


\section{References}

Andrews, D. W. K., and Monahan, J . C., 1992. An Improved Heteroskedasticity and Autocorrelation Consistent Covariance Matrix Estimator. Econometrica 60(4), 953-966.

Asea, P. K., and Corden, W. M., 1994. The Balassa-Samuelson Model: An Overview. Review of International Economics 2(3): 191-200.

Asea, P. K. and Mendoza, E. 1994. The Balassa-Samuelson Model: A General-Equilibrium Appraisal. Review of International Economics 2(3): 244-267.

Balassa, B., 1964. The Purchasing Power Parity Doctrine: a Reappraisal Journal of Political Economy 72(6): 584-596.

Bahmani-Oskooee, M.-O., 1992. A time series approach to test the productivity bias hypothesis in purchasing power parity. Kyklos 45(2): 227-236.

Bahmani-Oskooee, M. and Nasir, A. B. M., 2001. Panel data and productivity bias hypothesis. Economic Development and Cultural Change 49(2): 393-402.

Bahmani-Oskooee, M. and Nasir, A. B. M., 2005. Productivity Bias Hypothesis and the Purchasing Power Parity: A Review Article Journal of Economic Surveys, 19(4): 671-696.

Blanchard, O. and Giavazzi, F., 2003. Macroeconomic effects of regulation and deregulation in goods and labor markets. The Quarterly Journal of Economics 118(3):879-907.

Clague, C. K., 1986. Determinants of national price level: Some empirical results. The Review of Economics and Statistics 68(2): 320-323.

Clague, C. K., 1988. Purchasing power parities and exchange rates in Latin America. Economic Development and Cultural Change 36: 529-541.

Conway, P., and Nicoletti, G., 2006. Product market regulation in the nonmanufacturing sectors of OECD countries: measurement and highlights, OECD Economics Department Working Paper No. 530.

De Gregorio J., Giovannini, A. and Wolf, H.C., 1994a. The behavior of nontradable goods prices in Europe: Evidence and interpretation. Review of International Economics 2(3): 284-305.

De Gregorio J., Giovannini, A. and Wolf, H.C., 1994b. International Evidence on Tradables and Nontradables Inflation European Economic Review 38(6):1225-1244.

Dornbusch R., 1987. Exchange rates and pricesAmerican Economic Review 77(1):93-106. 
Egert, B., Drine, I., Lommatzsch, K. and Rault, C., 2003. The BalassaSamuelson effect in Central and Eastern Europe: Myth or reality? Journal of Comparative Economics 31(3): 552-572.

Frankel, J., 2006. The Balassa-Samuelson Relationship and the Renmibi, Harward Working Paper.

Gros, D., 2011. Sovereign Debt vs Foreign Debt in the Eurozone, CEPS Commentaries 12 May.

Heston, A., Summers, R. and Aten, B., 2011. Penn World Table Version 7.0, Center for International Comparisons of Production, Income and Prices at the University of Pennsylvania.

Hsieh, D. A., 1982. The determination of the real exchange rate: The productivity approach. Journal of International Economics 12(3-4): 355-362.

Im, K.S., Pesaran, M.H. and Shin, Y., 2003. Testing for Unit Roots in Heterogeneous Panels Journal of Econometrics 115(1): 53-74.

Krugman, P., 1986. Pricing to market when the exchange rate changes, NBER Working Papers 1926, National Bureau of Economic Research, Inc.

Maddala,G. S. and Wu, S., 1999. A Comparative Study of Unit Root Tests with Panel Data and A New Simple Test Oxford Bulletin of Economics and Statistics 61(0): 631-652.

Mark, N. C., and Sul, D., 2003. Cointegration vector estimation by panel DOLS and long-run money demand Oxford Bulletin of Economics and Statistics 65(5): 655-680.

Merler, S., and Pisani-Ferry, J., 2012. Sudden Stops in the Euro Area Bruegel Policy Contribution 2012:06, March.

Kao, C., and Chiang, M.-H., 2001. On the Estimation and Inference of a Cointegrated Regression in Panel Data. Advances in Econometrics, 15: 179-222.

Kravis, I. B. and Lipsey, R. E., 1983. Toward and explanation of National price levels. Princeton Studies in International Finance. Princeton, NJ: Princeton University, International Finance Section.

Obstfeld, M., 1994. Trending Real Exchange Rates. University of California at Berkeley Center for International and Development Economics Research Working Paper, no. C93-011, (1993).

Obstfeld, M., and Rogoff, K., 1996. Foundations of International Macroeconomics, Cambridge: MIT Press, (1996).

OECD, 2011. Product Market Regulation Database

Pedroni, P., 1997. Pedroni, P., 1997. Panel cointegration : asymptotic and finite sample properties of pooled time series with an application to the 
PPP hypothesis : new results, Indiana University Working Paper.

Pedroni, P., 1999. Critical Values for Cointegration Tests in Heterogeneous Panels with Multiple Regressors. Oxford Bulletin of Economics and Statistics 61(0): 653-670.

Pedroni, P., 2001. Fully modified OLS for heterogeneous cointegrated panels Advances in Econometrics 15:93-130.

Pedroni, P., 2004. Panel Cointegration; Asymptotic and Finite Sample Properties of Pooled Time Series Tests with an Application to the PPP Hypothesis Econometric Theory 20: 597-625.

Pesaran, M. H., 2007. A simple panel unit root test in the presence of crosssection dependence, Journal of Applied Econometrics 27(2): 265-312.

Phillips, P.C.B., 1995. Fully modified least squares and vector autoregression Econometrica 63(5):1023-1078.

Phillips, P.C.B., Hansen, B.E., 1990. Statistical inference in instrumental variables regressions with I(1) processes Review Economic Studies 57(1): 99-125.

Phillips, P. C. B. and Moon, H. R., 1999. Linear regression limit theory for non stationary panel data, Econometrica, 67:1057-1111.

Robinson, J., 1947. Essays in the theory of Employment, Blackwell

Rodrik, D., 2008. The Real Exchange Rate and Economic Growth, Brookings Papers on Economic Activity 2008 Fall:365-412

Rogoff, K. 1992. Traded goods consumption smoothing and the random walk behavior of the real exchange rate. Bank of Japan Monetary and Economic Studies 10(2): 1-29.

Saikkonen, P., 1991. Asymptotically efficient estimation of cointegration regressions Econometric Theory 7(1): 1-21.

Samuelson, P.A., 1964. Theoretical Notes on Trade Problems Review of Economics and Statistics 46(2): 145-164.

Sheng, Y. and Xu, X., 2011. Real exchange rate, productivity and labor market frictions Journal of International Money and Finance 30(3): 587603.

Stock, J. H. and Watson, M. W., 1993. A simple estimator of cointegrating vectors in higher order integrated systems Econometrica 61(4):783-820.

Strauss, J., 1995. Real exchange rates, PPP and the relative prices of nontraded goods. Southern Economic Journal 61(4): 991-1005.

Strauss, J., 1996. The cointegration relationship between productivity, real exchange rates, and purchasing power parity. Journal of Macroeconomics 
18(2): 299-313.

Strauss, J., 1999. Productivity differentials, the relative price of non tradables and real exchange rates. Journal of International Money and Finance, 18(3): 383-409.

Turnovsky, S. and Sen, P., 1995. Investment in a two-sector dependent economy. Journal of the Japanese and International Economies 9(1): 29-55

Venn D., 2009. Legislation, collective bargaining and enforcement: Updating the OECD employment protection indicators.

Westerlund, J. 2007. Testing for Error Correction in Panel Data. Oxford Bulletin of Economics and Statistics 69(6): 709-748. 